\title{
Retraction
}

\section{Retracted: A Simple HPLC-UV Method for the Determination of Glutathione in PC-12 Cells}

\author{
Scientifica \\ Received 1 February 2022; Accepted 1 February 2022; Published 24 February 2022 \\ Copyright (C 2022. This is an open access article distributed under the Creative Commons Attribution License, which permits \\ unrestricted use, distribution, and reproduction in any medium, provided the original work is properly cited.
}

Scientifica has retracted the article titled "A Simple HPLCUV Method for the Determination of Glutathione in PC-12 Cells" [1], due to concerns with data permissions. The listed authors did not collect the data presented in the article and did not possess the necessary permissions for publication of the data. It was found that the data were collected and owned by Ganesh K. Sittampalli and colleagues, and the article is therefore retracted from the journal with the agreement of the editorial board. The authors agree to the retraction.

\section{References}

[1] R. N. Appala, S. Chigurupati, R. V. V. S. S. Appala, K. Krishnan Selvarajan, and J. I. Mohammad, "A Simple HPLC-UV Method for the Determination of Glutathione in PC-12 Cells," Scientifica, vol. 2016, Article ID 6897890, 6 pages, 2016. 